\title{
Nitric oxide induces MUC5AC mucin in respiratory epithelial cells through PKC and ERK dependent pathways
} Jeong Sup Song*, Chun Mi Kang, Moon Bin Yoo, Seung Joon Kim, Hyung Kyu Yoon, Young Kyoon Kim, Kwan Hyung Kim, Hwa Sik Moon and Sung Hak Park

Address: Department of Internal Medicine, ST Mary's hospital, Catholic University Medical College. \#62, Yeoi-Do Dong, Young Dung Po Gu, Seoul, Korea

Email: Jeong Sup Sont* - jssong@catholic.ac.kr; Chun Mi Kang - doroshi73@hanmail.net; Moon Bin Yoo - mbyou@paran.com; Seung Joon Kim - cmcksj@catholic.ac.kr; Hyung Kyu Yoon - cmcyhg@catholic.ac.kr; Young Kyoon Kim - youngkim@catholic.ac.kr; Kwan Hyung Kim - kwan-kim@catholic.ac.kr; Hwa Sik Moon - hsmoon@catholic.ac.kr; Sung Hak Park - cmcpsh@catholic.ac.kr

* Corresponding author

Published: 29 March 2007

Respiratory Research 2007, 8:28 doi:10.1 186/I 465-992I-8-28
Received: II October 2006

Accepted: 29 March 2007

This article is available from: http://respiratory-research.com/content/8/I/28

(c) 2007 Song et al; licensee BioMed Central Ltd.

This is an Open Access article distributed under the terms of the Creative Commons Attribution License (http://creativecommons.org/licenses/by/2.0), which permits unrestricted use, distribution, and reproduction in any medium, provided the original work is properly cited.

\begin{abstract}
Background: Nitric oxide (NO) is generally increased during inflammatory airway diseases. This increased NO stimulates the secretion of mucin from the goblet cell and submucosal glands but the mechanism is still unknown precisely. In this study, we investigated potential signaling pathways involving protein kinase $C$ (PKC) and mitogenactivated protein kinase (MAPK) in the NO-induced MUC5AC mucin gene and protein expression in A549 cells.

Methods: Nitric oxide was donated to the A549 cells by NOR-I. MUC5AC mucin levels were assayed by enzyme-linked immunosorbent assay (ELISA). MUC5AC promoter activity was determined by measuring luciferase activity after the lysing the transfected cells. Activation of PKC isoforms were measured by assessing the distribution of the enzyme between cytosolic and membrane fractions using immunoblotting. Immunoblotting experiments using a monoclonal antibody specific to PKC isoforms were performed in the cytosol and membrane fractions from A549 cells. Western blot analysis for PERK and p38 were performed using the corresponding antibodies from the cell lysates after donating NO to the A549 cells by NOR-I.

Results: The transcriptional activity of MUC5AC promoter was maximal at the concentration of $0.1 \mathrm{mM}$ NORI for I hour incubation in transfected A549 cells. ( \pm )-(E)-methyl-2-((E)-hydroxyimino)-5-nitro-6-methoxy-3hexenamide (NOR-I) markedly displaced the protein kinase C (PKC) $\alpha$ and PKC $\delta$ from the cytosol to the membrane. Furthermore, the PKC- $\alpha$, Binhibitors, GÖ6976 (10 nM) and PKC $\delta$ inhibitors, rottlerin (4 $\mu \mathrm{M})$ inhibited the NOR-I induced migration of PKC $\alpha$ and PKC $\delta$ respectively. NOR-I also markedly increased the MUC5AC promoter activity and mRNA expression, mucin synthesis and ERKI/2 phosphorylation. The PKC inhibitors also inhibited the NOR-I induced MUC5AC mRNA and MUC5AC protein synthesis by inhibiting the activation of PKC $\alpha$ and PKC $\delta$ with ERKI/2 pathways.

Conclusion: Exogenous NO induced the MUC5AC mucin gene and protein through the PKC $\alpha$ and PKC $\delta$ - ERK pathways in A549 cells. Inhibition of PKC attenuated NO-mediated MUC5AC mucin synthesis. In view of this findings, PKC inhibitors might be useful in the treatment of bronchial asthma and chronic bronchitis patients where NO and mucus are increased in the bronchial airways.
\end{abstract}




\section{Background}

Production of NO is generally increased during inflammatory airway diseases such as asthma or bronchiectasis, or after exposure to irritant gases such as ozone [1]. NO is produced by the action of NO synthase (NOS) on Larginine and has many physiological and pathological roles. In chronic lower airway disease, the role of NO include pulmonary vasodilation, brochodilation, regulation of ciliary beat frequency and mucus production [2,3] and NOS is found in raised quantities in the airway epithelium of asthmatic patients[4].

Goblet cell hyperplasia and metaplasia are well established hallmarks of the airways of cigarette smokers, with and without chronic obstructive pulmonary disease (COPD). Enhanced epithelial mucin expression is believed to be the rate limiting step for goblet cell metaplasia [5]. Four gel forming mucins (MUC2, MUC5AC, MUC5B, and MUC19) are found in the lung. Of these, MUC5AC and MUC5B are the major respiratory mucins present in secretions from goblet cells and sub-mucosal glands, respectively [6]. MUC5AC has been shown to be stimulated by a wide variety of stimuli, including proinflammatory cytokines such as IL-9, IL-1 $\beta$ and tumor necrosis factor (TNF)- $\alpha[7,8]$, neutrophil elastase [9], epidermal growth factor receptor (EGFR) ligands [10], air pollutants [11] and bacterial products [12]. Oxidants in cigarette smoke and generated from asbestos fibers activate mitogen-activated protein kinase (MAPK) signalling cascades in lung epithelial cells [13]. Airway MUC5AC mucin is transcriptionally upregulated by cigarette smoke and is mediated by an AP-1 containing response element binding JunD and Fra-1 [14]. Furthermore, it is reported that PKC is involved in TNF- $\alpha$ or bacterial components induced MUC2 and MUC5AC overexpression in airway and middle ear epithelial cells or goblet cells [15].

NO donation by isosorbide dinitrate increased MUC5AC mucin secretion in the goblet cell line HT29-MTX [16] but suppressed chemokine production in keratinocytes [17]. There have been only a few studies investigating the role of NO in airway mucus secretion and much is still unknown about the role of PKC and MAPK pathways during upregulation of MUC5AC mucin secretion after donation of NO to the bronchial epithelial cells. In this study, we evaluated the effect of NO release on MUC5AC mucin production and the cell-signaling pathways involved in its regulation in the cell line A549. A549, a lung adenocarcinoma cell line, which has been used extensively as a model of respiratory epithelium and expresses both MUC5AC mRNA and glycoprotein [18].

In this study, we examined effects of NO on MUC5AC mucin synthesis and PKC-mediated second messenger pathways that may be involved in physiological functions of airway epithelium. Our results suggest that the PKC inhibitors inhibit the MUC5AC mRNA expression and mucin synthesis through inhibiting the PKC $\alpha$ and PKC $\delta$ ERK1/2-MUC5AC promoter pathways during donation of NO to the A549 cells.

\section{Materials and methods Cell culture}

Human lung adenocarcinoma-derived A549 cells were cultured in Roswell Park Memorial Institute (RPMI1640) media supplemented with 10\% fetal bovine serum (FBS), penicillin $100 \mathrm{U} / \mathrm{ml}$ and streptomycin $100 \mu \mathrm{g} / \mathrm{ml}$. Cells were maintained in a humidified incubator at $37^{\circ} \mathrm{C}$ with $95 \%$ air (vol/vol) and 5\% (vol/vol) $\mathrm{CO}_{2}$. The cells were replenished with fresh media every 2-3 days. The cell viability was periodically determined by trypan blue exclusion method.

\section{Agonists and inhibitors}

NOR-1 (Calbiochem, Darmstadt, Germany) was used as a $\mathrm{NO}$ donor. For control experiment, $\mathrm{NG}^{\mathrm{G}}$-nitro-L-arginine methyl ester (L-NAME) was used as a nitric oxide synthase inhibitor. Phorbol 12-myristate 13-acetate (PMA) was used as a protein kinase $\mathrm{C}$ (PKC) activator and inhibitors of PKC isoforms were used such as GÖ6976 (PKC $\alpha / \beta$ inhibitor), rottlerin (PKC $\delta$ inhibitor) and calphostin $\mathrm{C} \mathrm{(a}$ ubiquitous PKC inhibitor) which were purchased from Calbiochem (Darmstadt, Germany).

\section{MUC5AC protein measurement by ELISA}

MUC5AC protein was measured as described previously [19]. Briefly, $50 \mu \mathrm{l}$ of A549 cell lysate and $50 \mu \mathrm{l}$ of $2 \times$ carbonate/bicarbonate buffer were loaded into the 96-well ELISA plates and dried at $44^{\circ} \mathrm{C}$. The plates were washed three times with phosphate buffered saline (PBS) and blocked with $2 \%$ bovine serum albumin (BSA) for $1 \mathrm{~h}$ at room temperature. Then, it was incubated with $50 \mu \mathrm{l}$ of mouse anti-human MUC5AC Ab (1:100 Neomarker, Fremont, CA) for $1 \mathrm{~h}$. Plates were washed as above. Mucin detection was accomplished by addition of $100 \mu \mathrm{l} /$ well of a 1:2,500 dilution of peroxidase-conjugated goat antimouse IgG in PBS containing 15\% FBS and incubation for $1 \mathrm{~h}$. Plates were washed as above. Colorimetric reaction was developed with $100 \mu \mathrm{l} /$ well peroxidase substrate. Optical density (OD) measurements were obtained from an ELISA reader (BIO-TEK Instruments, Winooski, VT) at $405 \mathrm{~nm}$, with $450 \mathrm{~nm}$ serving as the reference wavelength. Results were calculated by dividing the OD reading for mucin during the experimental period by the OD reading for the L-NAME-treated baseline mucin. Results were expressed as percent of baseline control. 


\section{Measurement of nitrate and nitrite contents by Greiss assay}

Nitrate and nitrite were measured via the Greiss assay in the culture media. $1 \times 10^{5}$ of A549 cells were seeded on $100 \mathrm{~mm}$ dish and incubated until $80-90 \%$ confluency. After adapted in serum-free medium for $24 \mathrm{~h}$, cells were stimulated by NOR-1 for $3 \mathrm{~h}$ and supernatant was collected for Greiss assay. For Nitrate, $200 \mu \mathrm{l}$ of culture media and $200 \mu \mathrm{l}$ of nitrate reductase buffer that contained 50 $\mu \mathrm{M}$ NADPH, $40 \mathrm{mM} \mathrm{KH}_{2} \mathrm{PO}_{4}$ and $50 \mathrm{mU}$ nitrate reductase were mixed and incubated at room temperature for $2 \mathrm{~h}$. $200 \mu \mathrm{l}$ of $0.8 \% \mathrm{~N}$-1-naphthyl-ethylene diamine was added to same amounts of $2 \%$ sulfanilamide in $0.2 \mathrm{~N}$ $\mathrm{HCl}$. After incubation at room temperature for $10 \mathrm{~min}$ utes, the absorbance was measured on a spectrophotometry at $540 \mathrm{~nm}$. Nitrite of cell supernatant was determined using a mixture of $50 \mu \mathrm{l}$ of $2 \%$ sulfanilamide in $0.2 \mathrm{~N} \mathrm{HCl}$ and $50 \mu \mathrm{l}$ of $0.8 \% \mathrm{~N}$-1-naphthyl-ethylene diamine. Sodium nitrite was used as the standard.

\section{Transient Transfection}

In size of $1.3 \mathrm{~Kb}$ fragment MUC5AC promoter which was cloned into the pGL3-Basic luciferase vector was generously provided by Carol Basbaum (University of California, San Fransisco). A549 cells were seeded on 6-well plates $\left(2 \times 10^{5}\right.$ cells/well) and incubated for $48 \mathrm{~h}$ in serum free medium. Before transfection, the pGL3-MUC5AC3752pro luciferase reporter plasmid and control pGL3Basic vector were adjusted to $200 \mathrm{ng} / \mu \mathrm{l}$, and $\beta$-galactosidase was adjusted to $100 \mathrm{ng} / \mu \mathrm{l}$. The tube designated ' $\mathrm{A}$ ' contained $300 \mu \mathrm{l}$ of serum media, $5 \mu$ l of pGL3-MUC5AC3752pro luciferase reporter plasmid, $5 \mu$ of Plus reagent (GIBCO BRL), and $3 \mu \mathrm{l}$ of $\beta$-galactosidase, while 'B' tube contained $300 \mu \mathrm{l}$ of serum free media and $4 \mu \mathrm{l}$ of LIPOFECTAMINE $\beta$ REAGENT (GIBCO BRL). Each tube was mixed well in room temperature and $200 \mu$ lof the mixture was added to the wells containing A549 cells. After 5h, 1 $\mathrm{ml}$ of $20 \%$ FBS was added to the wells and further incubated for $24 \mathrm{~h}$.

\section{Luciferase assay}

In order to investigate the dose-dependency of $\mathrm{NO}$ on the MUC5AC promoter transcriptional activity, A549 cells were stimulated with $0.1,0.5,1$ and $1.5 \mathrm{mM}$ of NOR-1 for 1h. To examine the time-dependency, A549 cells were incubated with $0.1 \mathrm{mM}$ of NOR-1 for $30 \mathrm{~min}, 1,3,5$ and $24 \mathrm{~h}$ or PKC inhibitors for $30 \mathrm{~min}$. MUC5AC promoter activity was determined by measuring luciferase activity after the lysing the transfected cells and normalizing by co-transfection with the $\beta$-galactosidase expression plasmid, p $\beta$-gal control vector (Clontech). $\beta$-galactosidase activity was measured in the luminometer (Turner Designs, San Jose, CA) in accordance with the manufacturer's instructions. All transfections were performed in triplicate wells; results were reported as emitted light per well $($ mean $\pm \mathrm{SD})$.

\section{RT-PCR}

Total RNA was isolated using TRIzol ${ }^{\circledR}$ reagent (guanidium isothiocyanate-phenol mixture; Invitrogen, Charlsbad, CA) and chloroform from A549 cells. The RNA was incubated with $10 \mathrm{mM}$ dNTP, $0.1 \mathrm{M}$ DTT, $1 \mu \mathrm{l}$ random hexamer (1 pmole) and $1 \mu$ l SuperScript II $(200 \mathrm{U} / \mu \mathrm{l}$ Invitrogen, Charlsbad, CA) at $42^{\circ} \mathrm{C}$ for $50 \mathrm{~min}$, and then heat-inactivated at $70^{\circ} \mathrm{C}$ for $15 \mathrm{~min}$. After reverse transcription, PCR was performed with specific primer pairs for the MUC5AC and $\beta$-actin genes in a thermocycler (Bio-Rad, Hercules, CA) with an initial denaturation step of $94^{\circ} \mathrm{C}$ for $4 \mathrm{~min}$, followed by 28 cycles of $1 \mathrm{~min}$ at $94^{\circ} \mathrm{C}$, $1 \mathrm{~min}$ at $60^{\circ} \mathrm{C}, 1 \mathrm{~min}$ at $72^{\circ} \mathrm{C}$, with a final extension at $72^{\circ} \mathrm{C}$ for $7 \mathrm{~min}$. The following primer pairs were used for the PCR: MUC5AC, 5-TCC GGC CTC ATC TTC TCC-3 (forward) and 5-ACT TGG GCA CTG GTG CTG-3 (reverse); $\beta$-actin, 5-CAA GAG ATG GCC ACG GCT GCT TCC-3 (forward) and 5-TCC TTC TGC ATC CTG TCG GCA ATG-3 (reverse). The amplified PCR products were visualized on a $1 \%$ agarose gel by ethidium bromide staining.

\section{Separation of cytosol and membrane fractions and analysis of PKC isoforms}

A549 cells $\left(1 \times 10^{5}\right)$ were seeded on $100 \mathrm{~mm}$ dishes and cultured in $10 \mathrm{ml}$ until $80-90 \%$ confluency. After PKC inhibitors were treated for $30 \mathrm{~min}$, cells were washed and incubated with NOR-1 for $3 \mathrm{~h}$. Cells were harvested by centrifugation (1,000 rpm, $5 \mathrm{~min}$ ) and pumped by $1 \mathrm{ml}$ syringe for destruction. For cytosol and membrane fraction, destroyed cells were centrifuged at 50,000 rpm (200,500 g, rotor type 100Ti, Beckman Coulter, CA, USA) for $1 \mathrm{~h}$ at $4^{\circ} \mathrm{C}$, and then supernatant (cytosol fraction) was collected. After RIPA buffer (20 mM Tris-HCl, pH 7.4, $137 \mathrm{mM} \mathrm{NaCl}, 1$ \% Nonidet P-40, $0.25 \%$ sodium deoxycholate, $0.1 \%$ SDS, $1 \mathrm{mM}$ EDTA, $10 \mathrm{ug} / \mathrm{ml}$ aprotinin, 1 $\mathrm{mM}$ PMSF, $0.1 \mathrm{mM}$ sodium vanadate and $10 \mathrm{mM}$ sodium fluoride) was added into the pellet (membrane fraction), it was sonicated about $5 \mathrm{~s}$. Both fractions were quantitated by Bradford method and equal amount of protein $(20 \$ \mathrm{P})$ were resolved separately on $7.5 \%$ of SDS polyacrylamide gradient gels and transferred to polyvinylidene difluoride (PVDF) membrane. After blocking, membranes were incubated with anti-PKC antibodies (PKC sampler kit, BD Biosciences, CA, USA) followed by horseradish peroxidase (HRP)-conjugated antibodies. The detection was performed using a chemiluminescence method (Amersham Life Science). The density of signals was quantified using a densitometer.

\section{Western blot for MAPK}

Cultured A549 cells were washed 3 times with cold PBS. After detached from the plates using scrapping, the cells 
were harvested by centrifugation $(12,000 \mathrm{rpm}$ for $20 \mathrm{~min}-$ utes, $4^{\circ} \mathrm{C}$ ). Cells were destroyed by RIPA buffer on ice for 20 minutes. After destroyed cells were centrifuged, proteins were collected from supernatant and determined by Bradford method. 50 \$ of protein were separated on a discontinuous $10 \%$ and $4 \%$ PAGE gel and then the proteins were transferred to a PVDF membrane at $80 \mathrm{~V}$ for 1 h. The membrane was blocked with $5 \%$ skim milk in TBS buffer (10 mM Tris-Hcl, $150 \mathrm{mM} \mathrm{NaCl}, \mathrm{pH} 7.5)$ for $1 \mathrm{~h}$, and then incubated with the mouse anti-human p-ERK antibody (1:1000 Santa Cruz Biotechnology, Santa Cruz, CA) or rabbit anti-human p-p38MAPK antibody (1:1000 Cell signaling, Danvers, MA) at $4{ }^{\circ} \mathrm{C}$ overnight. The membrane was washed 3 times with TBST buffer (TBS $+0.1 \%$ Tween20) and incubated with HRP-conjugated secondary antibody $(1: 2000)$ at room temperature for $1 \mathrm{~h}$. The target protein was detected by ECL Kit (Amersham Pharmacia Biotech, Little Chalfont, Buckinghamshire, UK) using Xray film.

\section{Statistical analysis}

All data are presented as means \pm SE. Data obtained from all the experiments was analyzed by Kruskal-Wallis oneway non-parametric analysis of variance with post hoc evaluations by Mann-Whitney's rank sum test (SAS Institute, Cary, NC). A level of significance was considered at $\mathrm{p}$ $<0.05$.

\section{Results}

\section{NO concentration in A549 cells culture media}

The concentrations of NO in the culture medium of A549 cells after incubation with the synthetic NO donors, NOR1 for 3 hours were well correlated the concentrations of NOR-1 (Fig. 1). The NO concentrations in the culture medium were quantified by measuring nitrite and nitrate concentrations using the Greiss reaction [20].

\section{Effect of NO donation on MUC5AC promoter activity}

To determine whether NO was regulating MUC5AC transcription, we transfected A549 cells with a luciferase reporter pGL3-basic vector containing the $3.7 \mathrm{~kb} 5$ ' flanking region from the transcription start site of the human MUC5AC promoter. NOR-1 increased the transcriptional activity of MUC5AC promoter most markedly at the concentration of $0.1 \mathrm{mM}$ (Figure 2) and 60 minute incubation (Figure 3). MUC5AC transcriptional activity was increased after stimulation with NOR-1 for one hour between $0.1 \mathrm{mM}$ and $1 \mathrm{mM}$ concentrations (Figure 2).

\section{Activation of PKC isoforms by NOR-I}

To confirm the role of PKC activation in the effect of $\mathrm{NO}$ on MUC5AC mucin synthesis in A549 cells, we assessed the effects of NOR-1 on PKC $\alpha$. Activation of PKC $\alpha$ was measured by assessing the distribution of the enzyme between cytosolic and membrane fractions using immunoblotting, because translocation of the enzyme from the

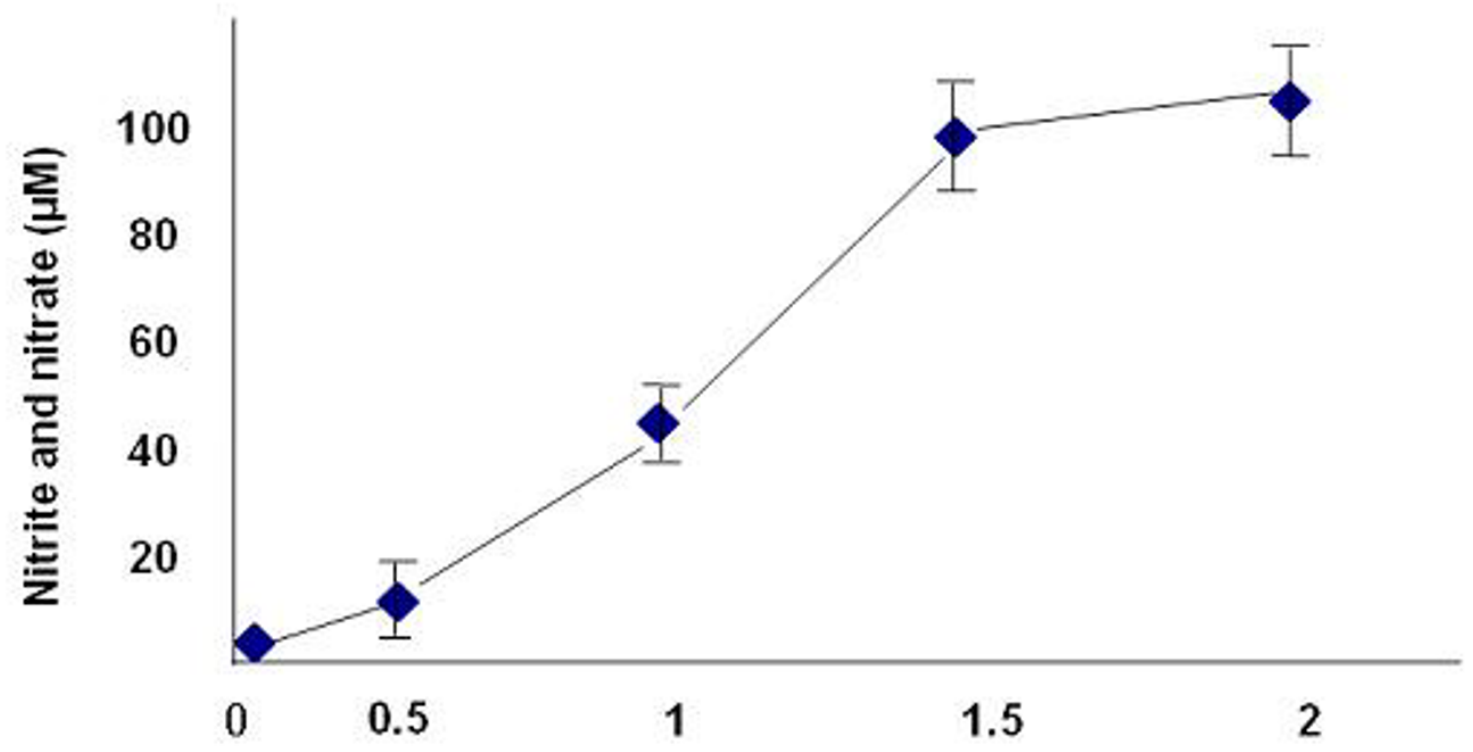

NOR-1 (mM)

\section{Figure I}

Effects of the NO donor, NOR-I on nitric oxide secretion from the A549 cells. The nitrite and nitrate concentrations were measured at $540 \mathrm{~nm}$ by Griess reagent method after stimulation with different concentrations of NOR-I for 3 hours. 


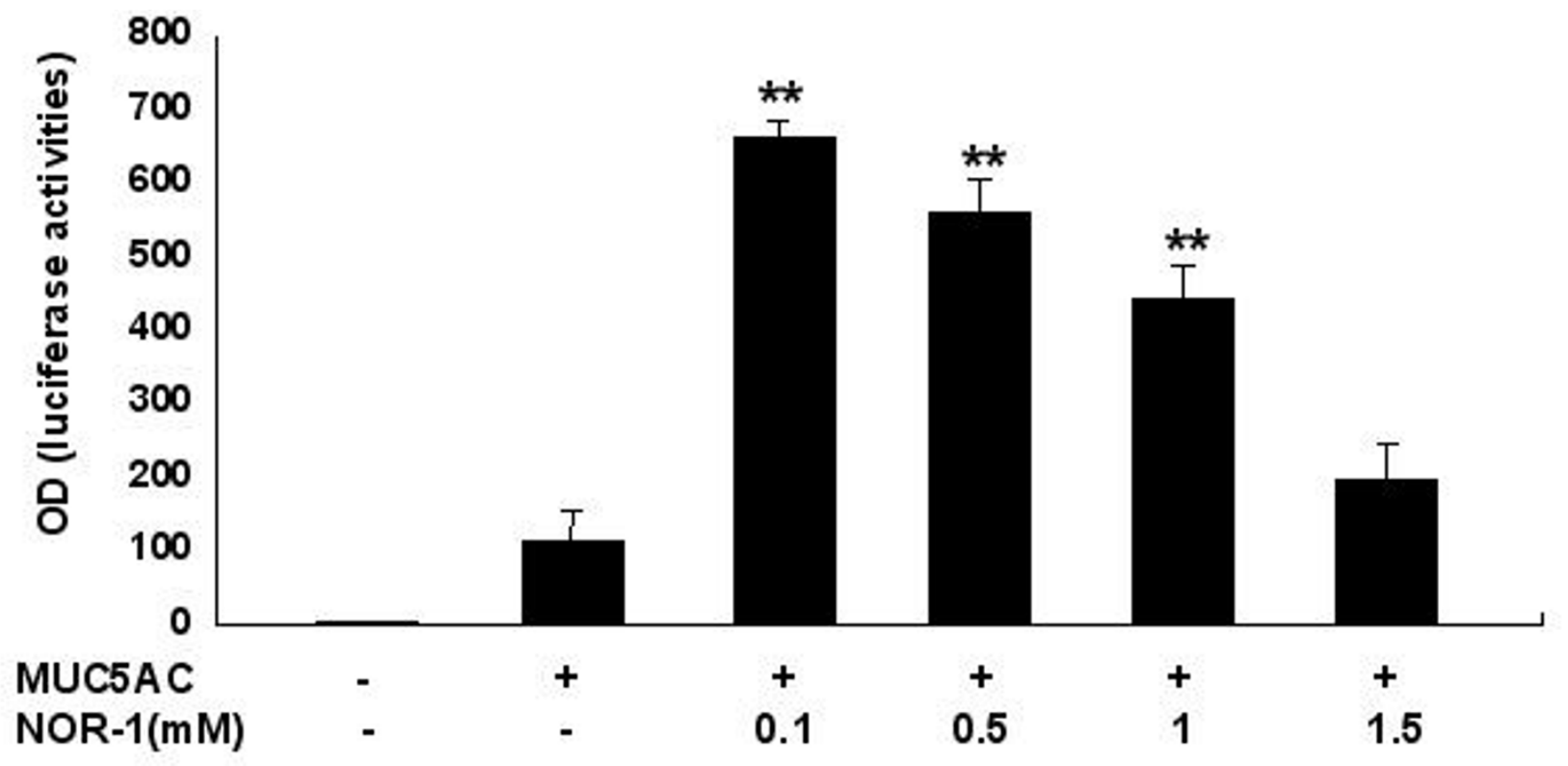

Figure 2

NOR-I increased the transcriptional activity of MUC5AC promoter. A549 cells were transfected with MUC5AC promoter. The transfected cells were treated with vehicle or different concentrations of NOR-I for I hr and then harvested for measurement of luciferase activities. ** significantly different, $\mathrm{P}<0.0$ I, from MUC5AC promoter-alone transfection group.

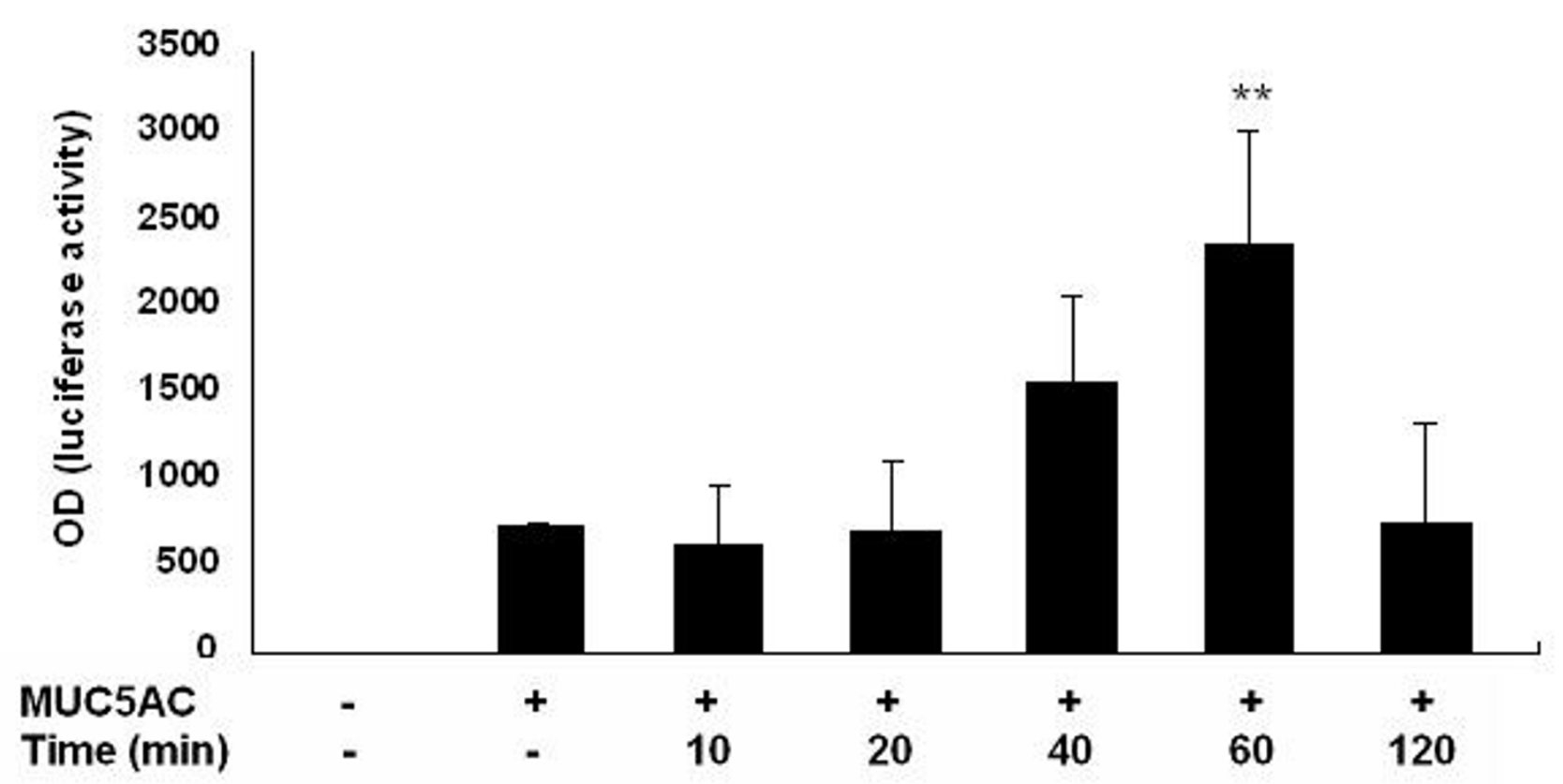

Figure 3

Time course of the effect of NOR-I on MUC5AC promoter activity. A549 cells were transfected with vehicle or MUC5AC promoter. Transfected cells were stimulated with $0.1 \mathrm{mM}$ of NOR-I and the transcriptional activity of MUC5AC promoter was measured at 10, 20, 40,60 and 120 min. after exposure. ** significantly different, p $<0.01$, from MUC5AC promoter-alone transfection group. 

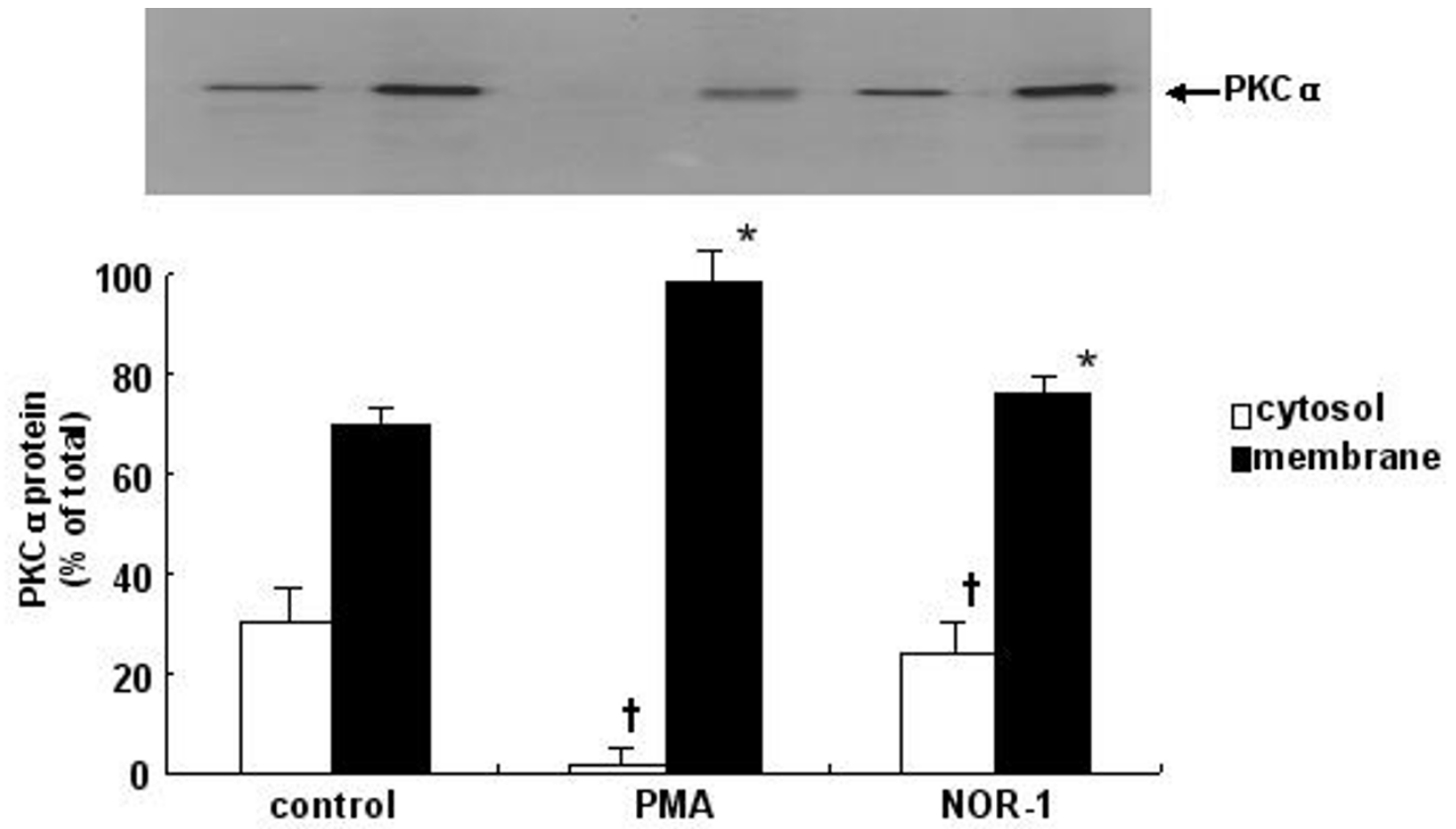

Figure 4

Effects of NO donor and PMA on the distribution of PKC $\alpha$ in A549 cells. A549 cells were exposed to NOR-I (0.5 mM) or PMA (I $\mu \mathrm{M})$ for one hour and then fractionated. Proteins of equal amounts were separated by SDS-PAGE, transferred, incubated with anti-PKC $\alpha$ antibodies, and detected using a chemiluminescence method. The results were expressed as means \pm SE of three independent experiments. ${ }^{*} p<0.01$ versus control membrane. $\dagger p<0.01$ versus control cytosol.

cytosolic fraction to the membrane fraction correlates with activation of the enzyme. As shown in Figure 4, incubation with NOR-1 for one hour resulted in significant translocation of PKC $\alpha$ from the cytosolic fraction to membrane fraction. The translocation of PKC $\alpha$ was more prominent during incubation with $1 \mu \mathrm{M}$ phorbol 12-myristate 13-acetate (PMA), a PKC activator. Next, we tested the effect of NOR-1 on PKC isoforms expression in A549 cells. As shown in figure 5, $0.5 \mathrm{mM}$ NOR-1 induced migration of PKC $\alpha$ and PKC $\delta$ from the cytosol to the membrane. The coincubation with PKC $\alpha$, $\beta$ inhibitors, GÖ6976 $(10 \mathrm{nM})$ and PKC $\delta$ inhibitors, rottlerin $(4 \mu \mathrm{M})$ inhibited the NOR-1 induced migration of PKC $\alpha$ and PKC $\delta$ respectively. NOR-1 induced migration of PKC $\alpha$ and PKC $\delta$ were also inhibited by $0.5 \mathrm{uM}$ calphostin $\mathrm{C}$, a general PKC inhibitor.

\section{Effect of NOR-I and PKC inhibitors on mucin secretion}

As illustrated in Figure 6, NOR-1 stimulated MUC5AC mucin synthesis by A549 cells. The increased mucin synthesis elicited by the NOR-1 was reversed with the preincubation with GÖ6976, rottlerin and calphostin-C. No cytotoxic effects were observed.

\section{NOR-I phosphorylated ERKI/2 but not P38 MAPK}

As illustrated in Figure 7, exposure of A549 cells to NOR1 caused a phosphorylation of ERK1/2 and this increased phosphorylation was inhibited with PD98059 (a specific MEK inhibitor), and PKC inhibitors (GÖ6976, rottlerin and calphostin C). However, the effects of NOR-1 on P38 MAPK phosphorylation was not noted.

\section{Effect of NOR-I and PKC inhibitors on MUC5AC mRNA expression}

NOR-1 increased the MUC5AC mRNA expression and the PKC inhibitors (GÖ6976, rottlerin and calphostin C) inhibited NOR-1 induced MUC5AC mRNA expression (Figure 8).

\section{Discussion}

The present study clearly demonstrates a potent stimulatory effects of NO donor on MUC5AC mucin secretion from A549 cells. Activation of the PKC $\alpha$ and PKC $\delta$ with ERK1/2 mediated NO donor induced MUC5AC mucin gene expression and mucin synthesis. We used NOR-1 as a NO donor which releases NO with a more rapid kinetics [21]. NO donors suppress chemokine production by inhibiting nuclear factor-kB and STAT-1 [22]. The role of $\mathrm{NO}$ in the regulation of inflammatory responses has been extensively investigated. However, there have been only a few studies investigating the role of NO in mucus secretion with conflicting results. On the one hand, NO inhibited mucus secretion in ferret trachea in vitro [23] and on the other hand, it had a stimulatory role in the mucus 

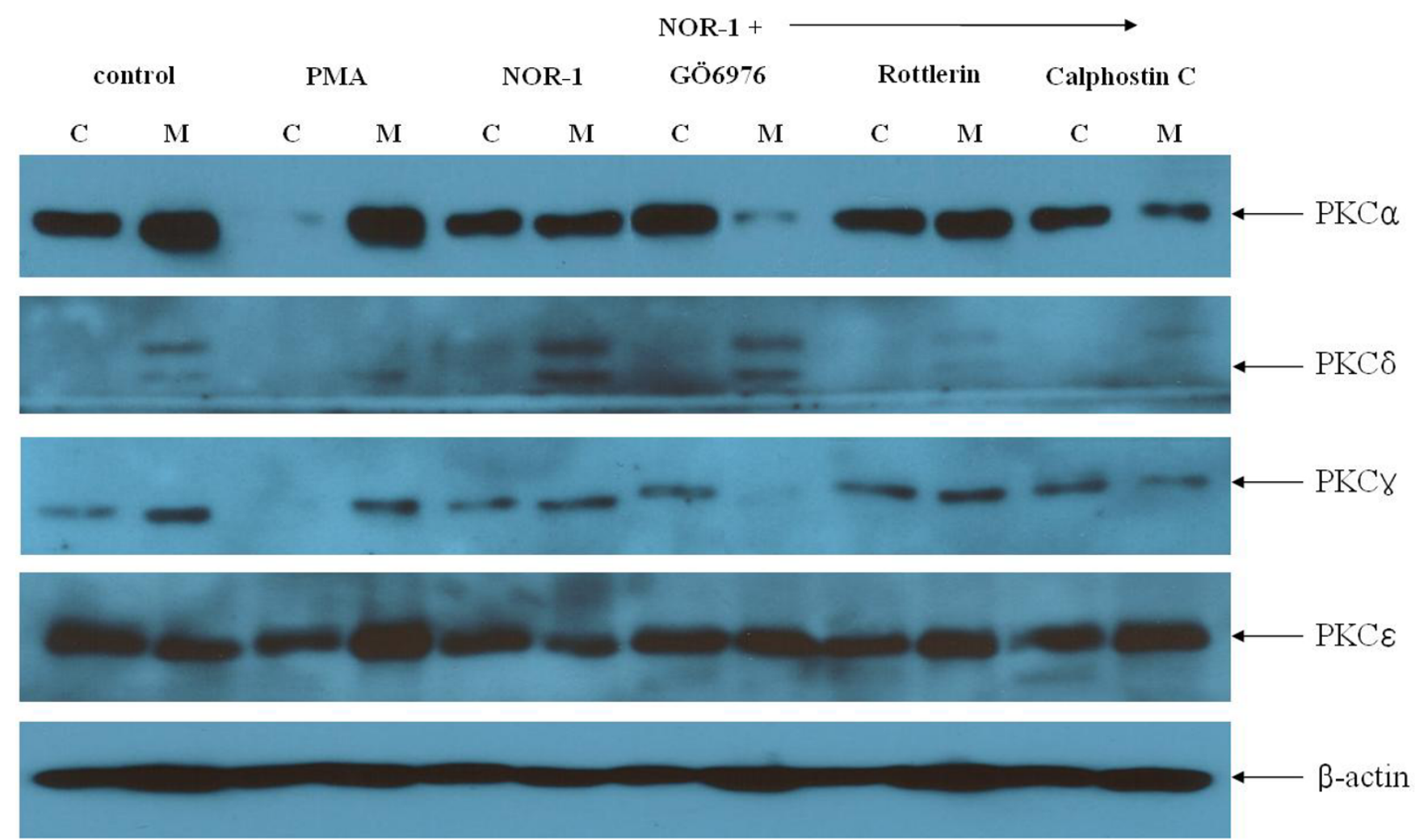

\section{Figure 5}

Effects of NOR-I on PKC isoforms expression in A549 cells. Cell extracts were portioned into cytosol (C) and membrane (M) fractions as described under "Materials and Methods." PKC isoforms were detected by Western blotting. NOR-I (0.5 mM) induced migration of PKC $\alpha$ and PKC $\delta$ but not PKC $\gamma$ and PKC $\varepsilon$ from the cytosol to the membrane. PKC- $\alpha, \beta$ inhibitors, GÖ6976 (I0 nM) and PKC $\delta$ inhibitors, rottlerin $(4 \mu \mathrm{M})$ inhibited the NOR-I induced migration of PKC $\alpha$ and PKC $\delta$ respectively. NOR-I induced migration of PKC $\alpha$ and PKC $\delta$ were also inhibited by calphostin $C(0.5 \mu \mathrm{M})$.

secretion in isolated submucosal gland from feline trachea [24] or it had no effect on the mucus secretion in the rat trachea [25].

Protein kinase C (PKC) is a family of serine/threoninespecific protein kinases with at least 10 different isoforms [21]. The PKC family contains three types of isoforms; classical (cPKCs: $\alpha, \beta_{1}, \beta_{2}, \gamma$ ), novel (nPKCs: $\delta, \varepsilon, \eta, \theta, \mu$ ), and atypical (aPKCs: $\xi, \mathrm{l} / \lambda$ ). The classical isoforms are calcium and phorbol ester-activated, the novel are calciuminsensitive but activated by phorbol esters, and the atypical isoforms are both calcium and phorbol ester-insensitive, with all isofoms activated by phosphatidyl serine[26].

The interaction between $\mathrm{NO}$ and PKC has been the subject of many studies, with most focused on the role of PKC in the regulation of $\mathrm{NO}$ production $[27,28]$. With regard to effects of $\mathrm{NO}$ on PKC, controversial results exist. NO inactivates PKC in a macrophage cell line [29]. On the other hand, NO activates PKC in hepatocytes [30], smooth mus- cle cells [31], and kidney cells [32]. In addition, NO was shown to mediate the stimulation of phospholipase $\mathrm{C}$ (PLC), a typical upstream step for PKC activation, by oxidant stress [33]. In a lot of inflammatory airway diseases, tumor necrosis factor (TNF)- $\alpha$ is involved in bronchoconstriction, pulmonary edema, and production of cytokines and lipid mediators. TNF- $\alpha$ stimulates mucin secretion via an intracellular pathway that appears to involve endogenously produced NO [34]. NO mediates many of its intracellular effects through activation of soluble guanyl cyclase with subsequent increased cyclic guanosine monophosphate (cGMP) production [35]. Recently NO has also been demonstrated in goblet cells to upregulate MUC5AC production [16].

In this study, NOR-1 directly increased the transcriptional activity of transfected MUC5AC promoter, indicating that NO-induced upregulation of MUC5AC mRNA occurs at the transcriptional level. NOR-1 also moved the PKC $\alpha$ and PKC $\delta$ from the cytosol to the membrane and this 


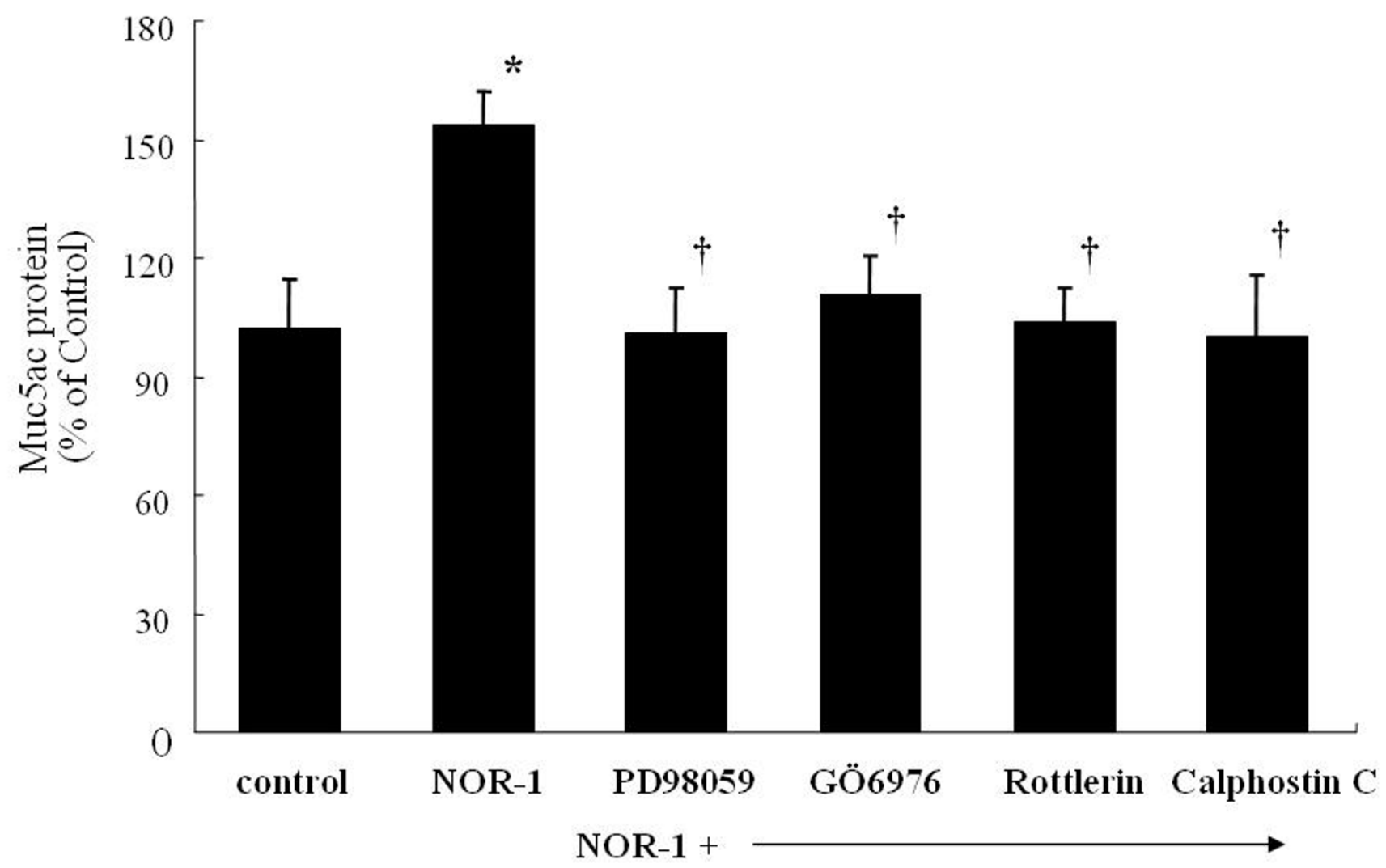

\section{Figure 6}

Effects of NOR-I and PKC inhibitors on the MUC5AC mucin synthesis from the A549 cells. A549 cells were exposed to NOR-I $(0.5 \mathrm{mM})$ in the presence of ERK-inhibitor, PD98059 $(40 \mu \mathrm{M})$ or PKC- $\alpha, \beta$ inhibitors, GÖ6976 (I0 nM) or PKC- $\delta$ inhibitors, rottlerin $(4 \mu \mathrm{M})$ or specific PKC inhibitors, Calphostin $C(0.5 \mu \mathrm{M})$. The results were expressed as means \pm SE of eight different experiments. ${ }^{*} p<0.05$ versus control, $\dagger p<0.05$ versus NOR-I stimulated cells.

intracellular activation of PKC was inhibited by PKC $\alpha$ inhibitor and PKC $\delta$ inhibitor.

Involvement of PKC in secretion of airway mucin in response to various stimuli has been indicated previously [35-38]. The specific PKC isoenzymes that contribute to PKC-induced mucin secretion have not been determined, although $\mathrm{PKC} \xi$ and $\mathrm{PKC} \delta$ have been suggested as potential candidates $[36,38,39]$. Recently human neutrophil elastase has been found to induce mucin secretion through a PKC $\delta$-mediated mechanism in human bronchial epithelial cells [40]. In this paper, we also found that the MUC5AC mucin synthesis by NOR-1 was inhibited by PKC inhibitors. As illustrated in figure 8, NOR-1 increased the MUC5AC mRNA expression and this increased expression was nearly completely inhibited by PKC inhibitors. The calphostin $\mathrm{C}$; a specific PKC inhibitor, rottlerin; a PKC $\delta / \theta$ inhibitor, GÖ6976; a PKC $\alpha / \beta$ inhibitor all inhibited the NOR-1 induced MUC5AC mRNA expression, MUC5AC mucin synthesis and extracellular signal-regulated kinases (ERKs) phosphorylations. Calphostin $\mathrm{C}$ is a specific PKC inhibitor that binds to the diacylglycerol (DAG) binding site of the enzyme to block its activity [41]. Our findings suggested that NO activated both $\alpha$ and $\delta$ forms of PKC which in turn involved in MUC5AC mucin synthesis in A549 cells. When we examined the translocation of PKC isoforms in response to NOR-1, NOR-1 activated the PKC $\alpha$ and PKC $\delta$ but not PKC $\gamma$ and PKCE (figure $5)$. As expected, the activation of PKC $\alpha$ by NOR-1 was inhibited by GÖ6976 and the activation of PKC $\delta$ by NOR1 was inhibited by rottlerin. Calphostin $\mathrm{C}$ inhibited the NOR-1 induced activation of both PKC $\alpha$ and PKC $\delta$.

Phorbol esters, such as phorbol 12-myristate 13-acetate (PMA), are important inflammatory stimuli that have been shown to modulate diverse cellular events through PKC activation [42]. PMA induced an increase in MUC2 gene expression and this induction involved PKC, was Ras and Raf dependent, required activation of mitogen-activated protein/ERK kinase (MEK) and extracellular regulated kinase (ERK) pathways, and led to the activation of the cis-acting transcription factor, NF-kB [43]. MUC5AC 

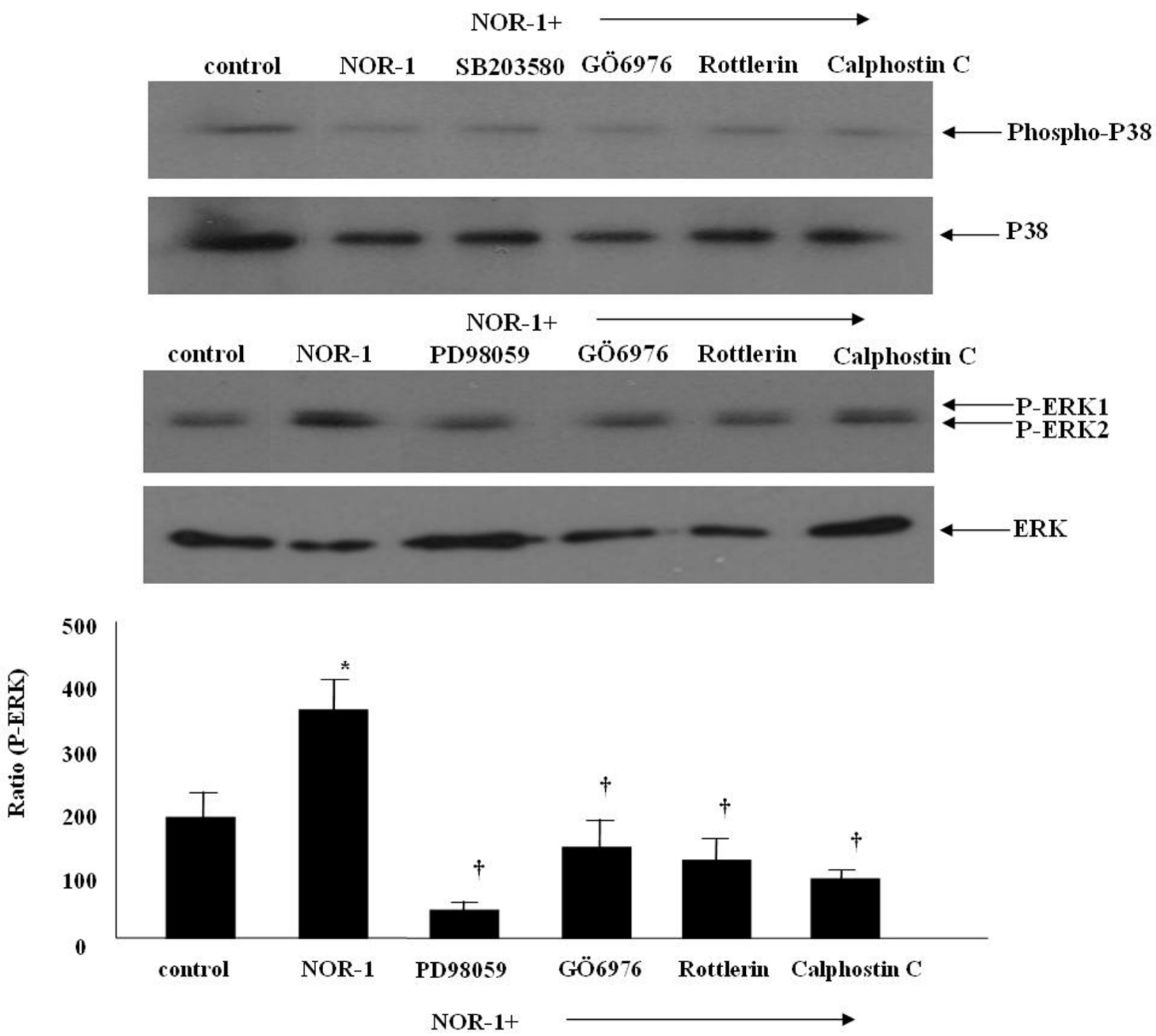

Figure 7

Effects of NOR-I and PKC inhibitors on the expression of phosphorylated p38 and ERKI/2 protein in A549 cells. NOR-I phosphorylated ERKI/2 but not p38 and PKC inhibitors, GÖ6976 (I0 nM), rottlerin (4 $\mu \mathrm{M})$, and Calphostin C (0.5 $\mu M)$ inhibited the ERKI/2 phosphorylation.

mucin was also induced by PMA through the Ras-RafMEK/ERK and specificity protein (Sp) 1 transcription factor dependent pathways [44].

The mitogen-activated protein kinase (MAPK) cascades consist of serine threonine kinases that are sequentially phosphorylated by upstream kinases (MAPKKK, MAPKK) and subdivided into three major pathways: ERKs, c-Jun$\mathrm{NH}_{2}$-terminal kinases (JNKs 1, 2, and 3) (also referred to as stress-activated protein kinases), and p38 kinases
$[45,46]$. MAPK cascades can be initiated by activation of receptor tyrosine kinases such as the epidermal growth factor receptor (EGFR) or other factors stimulating phosphorylation of upstream MAPKKK and MAPKK (MEK). Oxidative stress causes activation of EGFR-MEK-ERK1/2 pathways, resulting in mucin synthesis [47]. Recent studies have demonstrated cross-talk between p38 MAP kinase and ERK $[48,49]$. p38 MAP kinases are activated by a variety of agents, including environmental stress (e.g., reactive oxygen species, UV radiation), cytokines (e.g., interleukin 


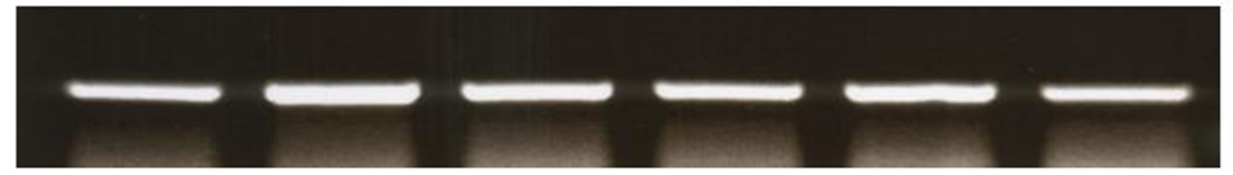

$\longleftarrow$ MUC5AC

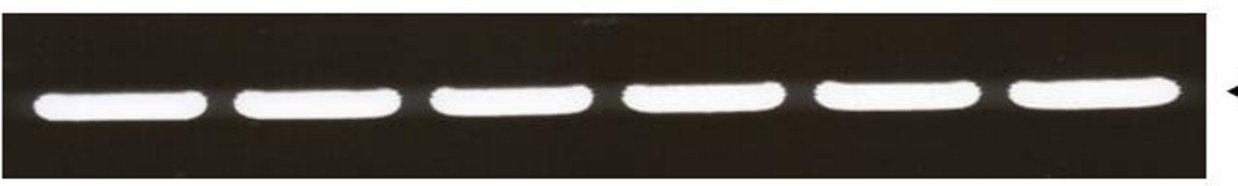

\section{$\longleftarrow \beta$-actin}

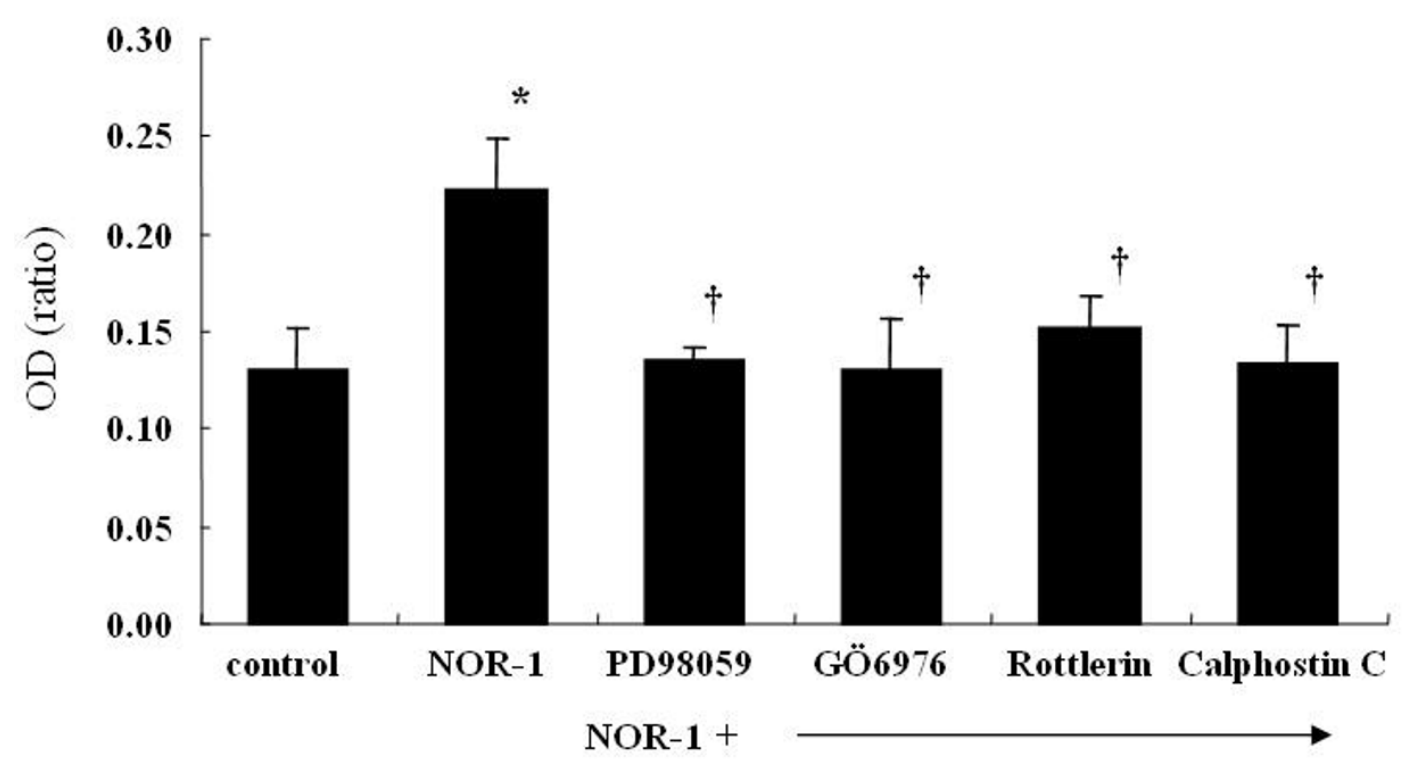

\section{Figure 8}

RT-PCR analysis of MUC5AC mRNA expression from A549 cells. Total RNA was extracted from confluent cultures and analyzed for the presence of MUC5AC and GAPDH transcripts by RT-PCR. The amplified products were run on I\% agaroseethidium bromide gels. The results were expressed as means $\pm \mathrm{SE}$ of six different experiments. ${ }^{*} \mathrm{P}<0.0 \mathrm{I}$ versus control, $\dagger<$ 0.05 versus NOR-I stimulated cells.

[IL]-1 $\beta$, tumor necrosis factor [TNF]- $\alpha$ ), or growth factors such as EGF and platelet-derived growth factor (PDGF) $[50,51]$.

In this study, we found that NO donation by NOR-1 activated ERK1/2 but not p38 and this ERK1/2 activation was inhibited by several types of PKC inhibitors and by MEK inhibitor, PD98059 (figure 7). These findings suggest that NO induced MUC5AC mucin through the PKC-MEKERK1/2 pathways in A549 cells. According to previous reports on respiratory tract and colon epithelial cells, production of mucin induced by gram-positive or gram-negative bacteria is dependent on tyrosine kinase such as the MEK1/2-MAPK signalling pathway [52-55]. This tyrosine kinase signal results in the activation of NF-kB in respira- tory tract epithelial cells, which are involved in the overproduction of mucin induced by Psudomonas aeruginosa [54].

Today, it is widely accepted that NO plays an important role in airway function. NO is an important mediator in the lung and has been shown to be associated with inflammatory lung diseases such as asthma and chronic bronchitis [56-58]. In addition, overproduction of mucus with altered rheologic properties is an important factor in the morbidity and mortality of asthma and chronic bronchitis $[59,60]$. Our results suggest that PKC inhibitors may be a promising new agents for the treatment of mucin hypersecretion in inflammatory airway diseases where NO is highly produced. 


\section{Abbreviations}

NOR1 = $( \pm)-($ E) -methyl-2-((E)-hydroxyimino $)$-5-nitro-6methoxy-3-hexenamide; $\mathrm{NO}=$ nitric oxide; $\mathrm{PKC}=$ protein kinase C; ELISA = enzyme linked immunosorbent assay; TNF- $\alpha=$ tumor necrosis factor $\alpha$; EGFR $=$ epidermal growth factor receptor; ERK = extracellular signal-regulated kinase; PMA = Phorbol 12-myristate 13-acetate

\section{Acknowledgements}

This study was supported by Research Grant of Catholic University Medical College in Seoul, Korea. The authors are indebted to late Carol Basbaum for her donation of MUC5AC promoter.

\section{References}

I. van der Vliet A EJ, Schgenaga MK, Cross CE: Reactive nitrogen species and Tyrosine nitration in the respiratory tract. Am Respir Crit Care Med 1999, 160:1-9.

2. B Z: Nitric oxide and asthma. Arch Dis Childhood 1995, 72:259-262.

3. Capper R GL, Pearson JP, Birchall JP: Effect of nitric oxide donation on mucin production in vitro. Clin Otololaryngol 2003 28:51-54.

4. Hamid Q, Springall DR, Riveros-Moreno V, Chanez P, Howarth P, Redington A, Bousquet J, Godard P, Holgate S, Polak JM: Induction of nitric oxide synthase in asthma. Lancet 1993, 342(88868887): $|5| 0-1513$

5. DF R: Airway goblet cells: responsive and adaptable front-line defenders. Eur Respir J 1994, 7:16909-II706.

6. Sharma P DL, Nielsen PA, Clausen H, Yankaskas JR, Hollingsworth MA, Engelhardt JF: MUC5B and MUC7 are differentially expressed in mucous and serous cells of submucosal glands in human bronchial airways. Am J Respir Cell Mol Biol 1998, 19:30-37.

7. Longphre M LD, Gallup M, Drori E, Ordonez CL, Redman T, et al: Allergen-induced IL-9 directly stimulates mucin transcription in respiratory epithelial cells. J Clin Invest 1999, 1 04: | 375-1382.

8. Koo JS KY, Jetten AM, Belloni P, Nettesheim P: Overexpression of mucin genes induced by interleukin-I beta, tumor necrosis factor alpha, lipopolysaccharide, and neutrophil elstase is inhibited by a retinoic acid receptor alpha antagonist. Exp Lung res 2002, 28:3 I 5-332.

9. Voynow JA YL, Wang Y, Horger T, Rose MC, Fischer BM: Neutrophil elastase increases MUC5AC mRNA and protein expression in respiratory epithelial cells. Am J Physiol 1999, 276:L835-L843.

10. Perrais M PP, Copin MC, Aubert JP, Van-Seuningen I: Induction of MUC2 and MUC5AC mucins by factors of the epidermal growth factor (EGF) family is mediated by EGF receptorl Ras/Raf/extracellular signal-regulated finase cascade and Sp I. J Biol Chem 2002, 277:32258-32267.

II. Longphre M LD, Li JD, Matovinovic E, Gallup M, Samet JM, Basbaum $\mathrm{CB}$ : Lung mucin production is stimulated by the air pollutant residual oil fly ash. Toxicol Appl Pharmacol 2000, I 62:86-92.

12. Wang B LD, Han J, Kim YS, Basbaum CB, Li JD: Novel cytoplasmic proteins of nontypeable Haemophilus influenza up-regulate human MUC5AC mucin transcription via a positive p38 mitogen-acivated protein kinase pathway and a negative phosphoinositide 3-kinase-Akt pathway. J Biol Chem 2002, 277:949-957.

13. Mossman BT, Lounsbury KM, Reddy SP: Oxidants and signaling by mitogen-activated protein kinases in lung epithelium. Am J Respir Cell Mol Biol 2006, 34(6):666-669.

14. Gensch E, Gallup M, Sucher A, Li D, Gebremichael A, Lemjabbar H, Mengistab A, Dasari V, Hotchkiss J, Harkema J, et al.: Tobacco smoke control of mucin production in lung cells requires oxygen radicals AP-I and JNK. J Biol Chem 2004, 279(37):39085-39093.

I5. Levine S], Larivee P, Logun C, Angus CW, Ognibene FP, Shelhamer JH: Tumor necrosis factor-alpha induces mucin hypersecretion and MUC-2 gene expression by human airway epithelial cells. Am J Respir Cell Mol Biol 1995, I 2(2):196-204.
16. Capper R, Guo L, Pearson JP, Birchall JP: Effect of nitric oxide donation on mucin production in vitro. Clin Otolaryngol Allied $\mathrm{Sci}$ 2003, 28(I):51-54.

17. Giustizieri ML AC, Scarponi C, Pita OD, Girolomoni G: Nitric oxide donors suppress chemokine production by keratinocytes in vitro and in vivo. Am J Pathol 2002, I61:1409-1418.

18. Berger JT, Voynow JA, Peters KW, Rose MC: Respiratory carcinoma cell lines. MUC genes and glycoconjugates. Am J Respir Cell Mol Biol 1999, 20(3):500-510.

19. Wright DT FB, Li C, Rochelle LG, Akley NJ, Adler KB: Oxidant stress stimulates mucin secretion and PLC in airway epithelium via a nitric oxide-dependent mechanism. Am J Physiol |996, 27 I:L854-L86I.

20. Green LC WD, Glogowski J, Skipper PL, Wishnok JS, Tannenbaum SR: Analysis of nitrate, nitrite, and [ $\left.{ }^{15} \mathrm{~N}\right]$ nitrate in biological fluids. Anal Biochem 1982, I 26:131.

2l. J H: The potential for isoenzyme-selective modulation of protein kinase C. FASEB J 1997, I I:649-669.

22. Percival MD QM, Campagnolo C, Claveau D, Li C: Inhibition of cathepsin $K$ by nitric oxide donors: evidence for the formation of mixed disulfides and a sulfenic acid. Biochemistry 1999 , 38: | 3574- I3583

23. Ramnarine SI, Khawaja AM, Barnes PJ, Rogers DF: Nitric oxide inhibition of basal and neurogenic mucus secretion in ferret trachea in vitro. Br J Pharmacol 1996, I I 8(4):998-1002.

24. Nagaki M, Shimura MN, Irokawa T, Sasaki T, Shirato K: Nitric oxide regulation of glycoconjugate secretion from feline and human airways in vitro. Respir Physiol 1995, I 02(I):89-95.

25. Bredenbroker D, Dyarmand D, Meingast U, Fehmann HC, Staats $P$, Von Wichert $P$, Wagner U: Effects of the nitric oxide/cGMP system compared with the CAMP system on airway mucus secretion in the rat. Eur J Pharmacol 200I, 4 I I (3):3 I9-325.

26. Chen Y, Zhao YH, Kalaslavadi TB, Hamati E, Nehrke K, Le AD, Ann DK, Wu R: Genome-wide search and identification of a novel gel-forming mucin MUCI9/Mucl9 in glandular tissues. Am J Respir Cell Mol Biol 2004, 30(2): I 55-I65.

27. Li S, Huang FL, Feng Q, Liu J, Fan SX, McKenna TM: Overexpression of protein kinase $\mathbf{C}$ alpha enhances lipopolysaccharideinduced nitric oxide formation in vascular smooth muscle cells. J Cell Physiol 1998, I 76(2):402-4I I.

28. Severn A, Wakelam MJ, Liew FY: The role of protein kinase $\mathbf{C}$ in the induction of nitric oxide synthesis by murine macrophages. Biochem Biophys Res Commun 1992, I 88(3):997-1002.

29. Gopalakrishna R, Chen ZH, Gundimeda U: Nitric oxide and nitric oxide-generating agents induce a reversible inactivation of protein kinase $\mathbf{C}$ activity and phorbol ester binding. J Biol Chem 1993, 268(36):27180-27185

30. Burgstahler AD, Nathanson $\mathrm{MH}$ : NO modulates the apicolateral cytoskeleton of isolated hepatocytes by a PKC-dependent, cGMP-independent mechanism. Am J Physiol 1995, 269(5 Pt I):G789-799

31. Nishio E, Watanabe $Y$ : Nitric oxide donor-induced apoptosis in smooth muscle cells is modulated by protein kinase $\mathbf{C}$ and protein kinase A. Eur J Pharmacol 1997, 339(2-3):245-25I.

32. Liang M, Knox FG: Nitric oxide activates PKCalpha and inhibits Na+-K+-ATPase in opossum kidney cells. Am J Physiol 1999, 277(6 Pt 2):F859-865.

33. Wright DT, Fischer BM, Li C, Rochelle LG, Akley NJ, Adler KB: Oxidant stress stimulates mucin secretion and PLC in airway epithelium via a nitric oxide-dependent mechanism. Am J Physiol 1996, 27 I(5 Pt I):L854-86I.

34. Adler KB, Fischer BM, Li H, Choe NH, Wright DT: Hypersecretion of mucin in response to inflammatory mediators by guinea pig tracheal epithelial cells in vitro is blocked by inhibition of nitric oxide synthase. Am J Respir Cell Mol Biol 1995, I3(5):526-530.

35. Fischer BM, Rochelle LG, Voynow JA, Akley NJ, Adler KB: Tumor necrosis factor-alpha stimulates mucin secretion and cyclic GMP production by guinea pig tracheal epithelial cells in vitro. Am J Respir Cell Mol Biol 1999, 20(3):4I3-422.

36. Abdullah LH, Bundy JT, Ehre C, Davis CW: Mucin secretion and PKC isoforms in SPOCI goblet cells: differential activation by purinergic agonist and PMA. Am J Physiol Lung Cell Mol Physiol 2003, 285(I):LI49-160. 
37. Abdullah LH, Conway JD, Cohn JA, Davis CW: Protein kinase C and $\mathrm{Ca2}+$ activation of mucin secretion in airway goblet cells. Am J Physiol 1997, 273(I Pt I):L20I-2IO.

38. Larivee P, Levine SJ, Martinez A, Wu T, Logun C, Shelhamer JH: Platelet-activating factor induces airway mucin release via activation of protein kinase $\mathrm{C}$ : evidence for translocation of protein kinase C to membranes. Am J Respir Cell Mol Biol 1994, II(2): 199-205.

39. Scott $\mathrm{CE}$, Abdullah $\mathrm{LH}$, Davis $\mathrm{CW}$ : $\mathbf{C a 2 +}$ and protein kinase $\mathrm{C}$ activation of mucin granule exocytosis in permeabilized SPOCI cells. Am J Physiol 1998, 275(I Pt I):C285-292.

40. Park JA, He F, Martin LD, Li Y, Chorley BN, Adler KB: Human neutrophil elastase induces hypersecretion of mucin from welldifferentiated human bronchial epithelial cells in vitro via a protein kinase C\{delta\}-mediated mechanism. Am J Pathol 2005, I67(3):65I-66I.

4I. Kobayashi E, Nakano H, Morimoto M, Tamaoki T: Calphostin C (UCN-1028C), a novel microbial compound, is a highly potent and specific inhibitor of protein kinase C. Biochem Biophys Res Commun 1989, I 59(2):548-553.

42. Carter CA: Protein kinase $C$ as a drug target: implications for drug or diet prevention and treatment of cancer. Curr Drug Targets 2000, I(2):163-183.

43. Lee HW, Ahn DH, Crawley SC, Li JD, Gum JR Jr, Basbaum CB, Fan NQ, Szymkowski DE, Han SY, Lee BH, et al.: Phorbol I 2-myristate 13-acetate up-regulates the transcription of MUC2 intestinal mucin via Ras, ERK, and NF-kappa B. J Biol Chem 2002, 277(36):32624-3263I.

44. Hewson CA, Edbrooke MR, Johnston SL: PMA induces the MUC5AC respiratory mucin in human bronchial epithelial cells, via PKC, EGF/TGF-alpha, Ras/Raf, MEK, ERK and SpIdependent mechanisms. J Mol Biol 2004, 344(3):683-695.

45. Brunekreef B, Holgate ST: Air pollution and health. Lancet 2002, 360(934I): $1233-1242$.

46. Pope CA 3rd, Burnett RT, Thun MJ, Calle EE, Krewski D, Ito K, Thurston GD: Lung cancer, cardiopulmonary mortality, and long-term exposure to fine particulate air pollution. Jame 2002, 287(9): I| $|32-||4|$.

47. Takeyama K, Dabbagh K, Jeong Shim J, Dao-Pick T, Ueki IF, Nadel JA: Oxidative stress causes mucin synthesis via transactivation of epidermal growth factor receptor: role of neutrophils. J Immunol 2000, I64(3): I546-1552.

48. Zhang $\mathrm{H}$, Shi X, Hampong M, Blanis L, Pelech S: Stress-induced inhibition of ERKI and ERK2 by direct interaction with p38 MAP kinase. J Biol Chem 200I, 276( I 0):6905-6908.

49. Singh RP, Dhawan P, Golden C, Kapoor GS, Mehta KD: One-way cross-talk between p38(MAPK) and p42/44(MAPK). Inhibition of p38(MAPK) induces low density lipoprotein receptor expression through activation of the p42/44(MAPK) cascade. J Biol Chem 1999, 274(28): 19593-19600.

50. Matsumoto T, Yokote K, Tamura K, Takemoto M, Ueno H, Saito $Y$, Mori S: Platelet-derived growth factor activates p38 mitogenactivated protein kinase through a Ras-dependent pathway that is important for actin reorganization and cell migration. J Biol Chem 1999, 274(20): I3954-I 3960.

5I. Harris VK, Coticchia CM, Kagan BL, Ahmad S, Wellstein A, Riegel AT: Induction of the angiogenic modulator fibroblast growth factor-binding protein by epidermal growth factor is mediated through both MEK/ERK and p38 signal transduction pathways. J Biol Chem 2000, 275(I5): 10802-108II.

52. Li JD, Dohrman AF, Gallup M, Miyata S, Gum JR, Kim YS, Nadel JA Prince A, Basbaum CB: Transcriptional activation of mucin by Pseudomonas aeruginosa lipopolysaccharide in the pathogenesis of cystic fibrosis lung disease. Proc Natl Acad Sci USA 1997, 94(3):967-972.

53. Dohrman A, Miyata S, Gallup M, Li JD, Chapelin C, Coste A, Escudier E, Nadel J, Basbaum C: Mucin gene (MUC 2 and MUC 5AC) upregulation by Gram-positive and Gram-negative bacteria. Biochim Biophys Acta 1998, I406(3):25I-259.

54. Li JD, Feng W, Gallup M, Kim JH, Gum J, Kim Y, Basbaum C: Activation of NF-kappaB via a Src-dependent Ras-MAPK-pp90rsk pathway is required for Pseudomonas aeruginosa-induced mucin overproduction in epithelial cells. Proc Natl Acad Sci USA 1998, 95(10):5718-5723.

55. Basbaum C, Lemjabbar H, Longphre M, Li D, Gensch E, McNamara N: Control of mucin transcription by diverse injury-induced sig- naling pathways. Am J Respir Crit Care Med 1999, 160(5 Pt 2):S44-48.

56. Barnes PJ, Belvisi MG: Nitric oxide and lung disease. Thorax 1993 , 48( I 0): $1034-1043$.

57. Barnes PJ, Liew FY: Nitric oxide and asthmatic inflammation. Immunol Today 1995, 16(3): I28-130.

58. Kharitonov SA, Yates D, Robbins RA, Logan-Sinclair R, Shinebourne EA, Barnes PJ: Increased nitric oxide in exhaled air of asthmatic patients. Lancet 1994, 343(8890): |33-| 35.

59. Sheehan JK, Richardson PS, Fung DC, Howard M, Thornton DJ: Analysis of respiratory mucus glycoproteins in asthma: a detailed study from a patient who died in status asthmaticus. Am J Respir Cell Mol Biol 1995, I 3(6):748-756.

60. Thornton DJ, Sheehan JK: From mucins to mucus: toward a more coherent understanding of this essential barrier. Proc Am Thorac Soc 2004, I(I):54-6I.
Publish with BioMed Central and every scientist can read your work free of charge

"BioMed Central will be the most significant development for disseminating the results of biomedical research in our lifetime. "

Sir Paul Nurse, Cancer Research UK

Your research papers will be:

- available free of charge to the entire biomedical community

- peer reviewed and published immediately upon acceptance

- cited in PubMed and archived on PubMed Central

- yours - you keep the copyright

Submit your manuscript here:

http://www.biomedcentral.com/info/publishing_adv.asp 